\title{
UCLA
}

UCLA Previously Published Works

Title

Bolster the Strength of States in Housing Policy

Permalink

https://escholarship.org/uc/item/8891w4d1

Journal

Housing Policy Debate, 29(1)

ISSN

1051-1482

Author

Lens, Michael C

Publication Date

2019-01-02

DOI

10.1080/10511482.2018.1506390

Peer reviewed 


\section{Bolster the Strength of States in Housing Policy}

\section{Michael C. Lens}

To cite this article: Michael C. Lens (2019) Bolster the Strength of States in Housing Policy, Housing Policy Debate, 29:1, 232-234, DOI: 10.1080/10511482.2018.1506390

To link to this article: https://doi.org/10.1080/10511482.2018.1506390

曲 Published online: 17 Dec 2018.

Submit your article to this journal

Џ Article views: 95

Q View related articles $ᄃ$

View Crossmark data \lceil

4 Citing articles: 1 View citing articles 


\title{
Bolster the Strength of States in Housing Policy
}

\author{
Michael C. Lens \\ Luskin School of Public Affairs, UCLA, Los Angeles, CA, USA
}

George Galster's article in this issue, "Neighborhoods and National Housing Policy: Toward Circumscribed, Neighborhood-Sensitive Reforms" (2019) is a very useful synthesis of the literature on housing subsidies and neighborhood dynamics coupled with a well-articulated proposal for several key reforms to assisted housing policy. Whereas the most humane and effective reform would be to make housing subsidies an entitlement and fund these programs accordingly, those articles have been written (Hertz, 2016; Landis \& McClure, 2010) and the federal government is not likely to move in this direction in the near term. Accordingly, Galster focuses on budget-neutral reforms. Galster is hopeful that-particularly if implemented in concert with one another-these reforms would increase the likelihood that housing subsidy recipients are able to access higher opportunity neighborhoods, and decrease the likelihood that assisted housing or households would negatively impact receiving neighborhoods.

The proposed set of reforms are well supported by empirical research and-if implemented-would likely improve outcomes for housing subsidy recipients and urban America at the same time. I hope Galster's piece helps jump-start a conversation about how to make many of them come to fruition politically and through implementation. This commentary provides a step in that direction, largely in the spirit of fine-tuning and addition.

The biggest omission in this piece is a discussion of how to better marshal and regulate the private housing market to provide more housing options for all. There is a natural tendency to talk about housing subsidy policy as entirely distinct from policies and regulations that affect the market-rate housing stock, but we are now at a point in which purely public housing subsidies are dwarfed in number by housing subsidy provision with a strong market-based component on both the supply side (chiefly through the Low-Income Housing Tax Credit, LIHTC) and the demand side (through the Housing Choice Voucher Program). Given that we have melded the public and private in our provision of housing subsidies, for better or worse, we can no longer talk about federal housing reforms without addressing local regulations against housing of all kinds.

This is particularly true given additional sources of the interconnectedness of private and public housing options. First, the vast majority of low-income households consume housing without any subsidy at all. The Center on Budget and Policy Priorities estimates that there are nearly 11 million households that earn less than $80 \%$ of Area Median Income and spend $50 \%$ of their income (or more) on rent, yet only about 5 million households receive housing subsidies (National and State Housing Fact Sheets \& Data, 2017). When we talk about where low-income households live and how they afford housing, we have to talk about the private market.

Second, the neighborhood resistance that so sharply constrains housing subsidy location and is a central feature to Galster's piece is very commonly applied to proposals for market-rate housing. This resistance is reflected in the vast swaths of American residential urban land zoned exclusively for singlefamily housing, which is more likely to be prohibitively expensive for low-income households. Whereas there is controversy over whether and how new, market-rate housing affects housing affordability and supply at the lower end of the price and income spectrum, we know for a fact that the same tools are 
used to resist multifamily construction whether it is subsidized or not. Federal housing policy should provide leadership and incentives to dismantle these structures of resistance.

This leads to a discussion on the ability of higher levels of government to influence housing and landuse outcomes when power lies at the local level. Galster proposes experimentation in regional housing institution-building, which he is careful to note is not a repackaging of past fantasies of centralized regional planning authorities. But what if we looked to a level of government-the state- that tends to hold more carrots and sticks than regions? California legislators have introduced several pieces of legislation in recent years - many failed, some successful — designed to rein in local control of land use. If the most populous state in the country can make inroads into housing and land use policy, perhaps states can experiment with running housing authorities. This would hopefully reduce friction across jurisdictional boundaries and increase the level of competence of these agencies.

Another important reform for federal leadership in this area is to make fair housing and housing production more of a coherent endeavor at the U.S. Department of Housing and Urban Development (HUD). HUD has both an Assistant Secretary for Fair Housing and an Assistant Secretary for Housing, running separate offices. Prior to the rollout of the Affirmatively Furthering Fair Housing (AFFH) rule under the Obama Administration, it was clear that the housing-production side of HUD served a clearer purpose, with a larger presence, than the fair housing side did. Whereas the AFFH rule is in retreat under Secretary Carson's HUD, the agency has never been clear about what to do when housing production and fair housing goals conflict, and how to craft policy to make these efforts more synergistic.

The biggest issue that I take with any individual reform proposed by Galster is with his suggestion that we further restrict the neighborhoods in which housing is built with public subsidy-he specifically mentions LIHTC and HOME. My concern is that any additional restrictions on the use of LIHTC funds, without increasing the value of the credit, are likely to produce less housing.

In any future discussions and progress on these reforms, serious attention must be paid to how potential changes might interact with one another, and Galster argues persuasively that the sum of combinations of these reforms would often be greater than its parts. Further attention must be paid to unintended consequences of these reforms, and how to craft policy and regulations that can minimize negative outcomes and build enduring support for fair and affordable housing. Galster was careful to craft budget-neutral reforms, but housing subsidy policy is often unpopular regardless of budget impact. Academics and policymakers should support efforts by advocates to build enduring coalitions to support policies that better serve recipients and neighborhoods alike.

\section{Disclosure Statement}

No potential conflict of interest was reported by the author.

\section{Notes on Contributor}

Michael C. Lens is an associate professor of urban planning and public policy at the University of California, Los Angeles (UCLA) Luskin School of Public Affairs. He conducts research on housing, neighborhood effects, and segregation by income and race, and has published several papers in housing, planning, and urban studies journals. He holds a PhD in Public Administration from New York University and a Master's in Public Policy from the University of Michigan.

\section{References}

Galster, G. (2019). Neighborhoods and national housing policy: Toward circumscribed, neighborhood-sensitive reforms. Housing Policy Debate, 29(1), 217-231

Hertz, D. K. (2016, May 1). Make housing vouchers an entitlement-We can afford it. City Observatory. Retrieved from http://cityobservatory.org/make-housing-vouchers-an-entitlement-we-can-afford-it/.

Landis, J. D., \& McClure, K. (2010). Rethinking federal housing policy. Journal of the American Planning Association, 76(3), 319-348. 
National and State Housing Fact Sheets \& Data. (2017, August 9). Center on budget and policy priorities. Retrieved from https://www.cbpp.org/research/housing/national-and-state-housing-fact-sheets-data. 